\title{
Language Revolt in Paradise: Recent Indonesian Non-Conventional Expressions
}

\author{
Yazid Basthomi \\ English Department, Faculty of Letters, Universitas Negeri Malang (State \\ University of Malang), Semarang 5, Malang 64145, East Java, Indonesia \\ e-mail: ybasthomi@um.ac.id; yazzbazz@yahoo.com
}

\begin{abstract}
Language is dynamic and, accordingly, language change is bound to occur. This article analyzes few recent Indonesian nonconventional expressions as properties which potentially motivate some changes in Bahasa Indonesia (Indonesian). Since the term "nonconventional" has to do with the notion of "convention", which is central to Saussurean linguistics, the analysis is carried out by means of Saussure's linguistic views. The analysis shows that the nonconventional expressions can be well accounted for using Saussure's theoretical propositions. However, as to why Indonesians come up with the non-conventional expressions is beyond pure Saussure's linguistic concepts. The article also touches upon the idea that the issue about nonconventional expressions (which may be deemed grammatical aberrations) poses a challenge to language planners.
\end{abstract}

Key words: non-conventional expressions, sign, paradigm, syntagm, language change

Language undertakes changes in some respects along the course of history (see for example, Burkette, 2001; Goss, 2002; Nawata, 2000). In fact, language change has been a significant interest of linguists (Romaine, 1994). A piece of gross evidence of language change is the split of one language into two or more languages in its later development. Malay and Bahasa Indonesia, which are now of two different entities, are widely believed that they once used to be one language. People also now recognize World Englishes instead of only single, monolithic English (Doyle, 1989; Norton, 1997; Flowerdew, 2001).

There are, however, some other changes which are not as apparent as the split of a language. Within a particular language, a novel accentuation, as a form of the change, might come to the fore. As is the case nowadays, people's mobility and exposure to different languages and cultures of 
others give rise to the possibility of language change. Pertinent to this, Romaine (1994, p. 134) notes that in about 1991/1992, young Swedes started to frequently use the word $n O ̈ r d$ which she believes as the Swedish form of the English word nerd.

A similar situation seems to hold true in Indonesia. In Bahasa Indonesia, for instance, certain words have recently enjoyed more recognition and wider use more than the others. Such a phenomenon is apparent in the language of media, especially, advertisement. This seems to apply to an emphatic modifier banget (similar to pretty, just, very, so) in the Indonesian media, be they electronic or print. A recent instance is Delon banget, an expression spoken by Ata, a presenter of 'Indonesian Idol' at its grand final contest on August 28, 2004, televised direct by RCTI.

Seemingly, the recent popularity of such a word is due to its nonconventional use. The normal orthography of banget has been frequently written in the media as BANGEEET. This suggests that certain words potentially gain certain credence due to its non-conventional use. When last year (as of May 19, 2008) I googled the words "KOPI BANGEEET", I found about 3,410 hits. This shows the wide popularity of the expression.

In spite of the fact that there has been a relatively sizeable literature on Indonesian linguistic manifestations (e.g., Aveling, 2004; Basthomi, 2007, 2009; Davies, 2005; Palupi, 2006; Susanto, 2007), there has been, to the present writer's knowledge, no document which deals with this recent phenomenon in Bahasa Indonesia. Since the instance we are discussing has been induced by the public, it falls into the category of "change from below" (Romaine, 1994, p. 140). We will touch further on this bottom-up issue of language change later in this article. And since the core issue is the notion of (non) convention which is central to Saussurean linguistics, the present article will account for the non-conventional expressions by referring mainly to Saussure's linguistic concepts.

\section{THEORETICAL ORIENTATION}

Linguistics should study, Saussure (1959) asserts, the system of conventions, i.e., words or grammar. These conventions are those which allow a sign, for instance, a word, to have meaning. So, the basic unit of meaning is sign and a system of signs constitutes a language (Rice \& Waugh, 1992, p. 5). What follows is a summary of Saussurean concepts of language. 
Sign is composed of a signifier and signified; the former is the 'wordimage', which might be visual or acoustic, and the latter the 'mental concept.' When we hear (acoustically) the word 'turtle dove', we develop the signified mental concept of 'turtle dove' in our mind. However, the notion of signifier and signified is separable on the analytic level only; the two are not divisible at the level of thought, for the word image cannot be broken up from the mental concept and the other way round.

A pivotal principle of Saussure's theory is that sign is 'arbitrary.' Such arbitrariness applies to the two levels of signifier and signified. As a signifier, 'elephant' has no necessary connection to the 'concept of elephant.' So, basically, people are free to employ any configuration of sounds or written shapes to signify 'elephant' - for instance, 'gnose.' Yet, as to why (English) people only use the signifier 'elephant' to refer to the concept of 'elephant' - a relatively giant animal having four legs, thick and tough skin, very long flexible nose, and two tusks - has to do with convention as put forth above.

Languages not only use different signifiers, but also divide "the phenomenal world differently" (p. 6). Language-specific concepts use different signifieds to articulate the phenomena. They further point out that one of the famous illustrations of this is the color spectrum, which actually forms a continuum. So, part of the spectrum which runs from blue to red does not consist of a series of different colors - blue, green, yellow, orange, red - existing independently of each other. Rather, the spectrum is a continuum which our language breaks up in a particular way.

As applies to our way to carve up the color continuum (e.g., Madurese tend to use 'biru' (blue) to refer to 'green' leaves), we come to know that each language slices up and constructs different meaningful categories and concepts. This means that, to some extent, concepts are language-specific and the speakers of a particular language tend to be naturalized to the world which their language system has produced. Living with a particular language tends to make us find the world that our language constructs look natural, correct, normal, and conventional. At this juncture, "Saussure's theory suggests that our world is constructed for us by our language and that 'things' do not have fixed essences or cores of meaning which preexist linguistic representation" (pp. 6-7).

Heeding back the color spectrum, we can find that green does not stand alone. In order to exist, the color green depends on the other colors around it. The color green is definable only by what is not (green). There is 
no 'essence' to the color, only a differentiation; green is recognizable because it is not purple, not black, not white, and not any other colors. So, green is generated in the system of difference.

The above mechanism, the system of difference, is how human language works. The differential place within that system is what allows any term to possess meaning. Any sign, for instance 'happiness', could not mean anything without the concept of not happiness. As human beings are bound to make classification, they need a system of difference, i.e., a basic binary system - happy/not happy, light/not light, and so forth. Since language is a lot more complex than this simple binary system, Saussure emphasized on the idea of 'system' of language. Without the system, individual elements (the signs) could not mean anything (Saussure, 1959).

The foregoing discussion has touched upon the idea that signs do not have any essential core of meaning. On the basis of this concept, languages are open to change. Therefore, as to how banget is now gaining a special credit is made possible by such a state. Yet, as to how banget means is dependent on its existence within the system of Bahasa Indonesia, which is complete at any one moment as any other living language.

Back to the notions of signifier and signified, signs (words) are different from each other, phonologically as well as morphologically; they are negative (of each other), even in relations to other signifiers. The idea of 'negative' refers to the fact that the signifiers negate any other signifiers. This negative characteristic is also true with what the words signify (the signifieds). However, the positive characteristics of words are also worth attending to. Saussure (1959) observes that if a sign (word) is seen in its totality, it is positive. It posits ideas. He refers to the instances that alteration of signifiers induces conceptual (signified) changes (p. 121). This seems to be true with uses of words in advertising or mass media in general and particularly the recent use of the word banget.

\section{GRAMMATICAL ABERRATION, SEMANTIC FIASCO, OR WHAT?}

One important idea that Saussure (1959) advocates is that signs operate in two ways. The first is paradigm. This is a set of signs from which the one to be used is chosen. Vocabulary can be said to be a paradigm. The second is the syntagm. It is the message into which the chosen signs are combined. Sentences can be said to be a syntagm. So, all 
messages incorporate the selection (from a paradigm) and the combination (into a syntagm). Applying the concepts of paradigm and syntagm as well as the subsequent notions of norm and deviation will be insightful.

In the application of the paradigm and syntagm, the discussion of norm and deviation is imperative (Fiske, 1982). A norm refers to the common practices of a group or society and is thus commonplace, predictable, and banal - the expected; pervasive and widely accepted conventions are close to the norm (Fiske, 1982). The non-conventional is a deviation from the norm. Yet, we need to bear in mind that normality and deviation have degrees. We also need to remember that in practice, the normal and the deviant are frequently in a continuum. Deviation frequently moves towards the normal position. Trousers for women used to be deviant; but, today, it has become much more normal. This also seems to be true with the use of non-conventional expressions. In what follows, we explore more about the use of the aforementioned instance of banget.

KOPI BANGET is a recent wording of the advertisement of candies with the trade-mark: KOPIKO. KOPI BANGET is deviant in that the syntagm

$$
\text { “... BANGET" }
$$

is normally completed by one of a set of words with particular characteristics, that is, words from a particular paradigm. In this case, the characteristics of the normal paradigm are words which can be categorized into 'degrees of comparison', which, in the 'traditional' grammar, are classified as 'adjective' and 'adverb'; this category is the filter. So, we can construct a paradigm sharing values of normality or deviance to complete the syntagm: "... BANGET" (see Figure 1).

The words jauh (far), dekat (close), tinggi (high/tall), rendah (low/short), enak (nice, delicious, good), manis (sweet), pahit (bitter), asam (sour), asin (salty), segar (fresh), susah (terrible), bahagia (happy), gembira (joyful), panas (hot), hangat (warm), sejuk (cool), dingin (cold), baik (good), and jahat (bad) share something in common. They all possess the characteristics which make them pass the filter as they meet the characteristics in the paradigm: degrees of comparison. So, we can say jauh (far), lebih jauh (farther), paling jauh (the farthest), dekat (close), lebih dekat (closer), paling dekat (the closest), and so forth. On the other hand, the words beras (rice), jagung (corn), ketela (cassava), kentang (potato), 
bayam (spinach), kubis (cabbage), seledri (celery), merica (pepper), tembakau (tobacco), cengkeh (clove), susu (milk), and kopi (coffee) do not pass through the filter because they fail to meet the characteristic of the paradigm. We cannot normally say beras (rice), lebih beras (ricer), paling beras (the ricest), jagung (corn), lebih jagung (corner), paling jagung (the cornest), and so on. They, normally, are available in different syntagms. By inserting KOPI into this particular syntagm (KOPI BANGET), the advertiser has (temporarily) attached to it the characteristics of its new paradigm, while retaining those of its original one (Fiske, 1982). By supplying KOPI with the characteristics of having degrees of comparison, the advertiser has given the word a new set of meanings that many readers find particularly imaginatively pleasing."

In other words, the phrase KOPI BANGET is working metaphorically in that it is taking a unit from one paradigm and inserting it into a syntagm which would normally be completed by a unit from another. By so doing, it is associating the characteristics of the paradigm in a new and often imaginatively striking way. All metaphors, in this sense, are deviations from the norms of language behavior (Fiske, 1982).

The phrase KOPI BANGET is actually the shortened one. Originally, it reads KOPI BANGEEET. Analysis of this phenomenon might also be elucidating. This has to do with the notion of signified, in this case, signified in the form of its phonetic sounds. By and large, Indonesians have the sound image (as a signified) that the word (as a signifier) BANGEEET will be pronounced /banə::t/. However, as the advertisement goes, and when the phrase KOPI BANGEEET shows up on TV, the dubbing sound expresses /ba::pət/. Again this is a deviation from the norm, the conventionally imprinted sound-image of the word BANGEEET. Subsequently, it gives another nuance to the advertisement. Again, to some extent, it might be, psychologically, (due to the audience's linguistic competence) pleasing.

More repercussions can still be found about the advertisement. BANGEEET is normally unavailable in the orthographic writing system of Bahasa Indonesia. It follows that, when the advertiser employs it, there is another deviation from the norm (BANGET), from the paradigm as stored by (likely) the majority of Indonesians. 


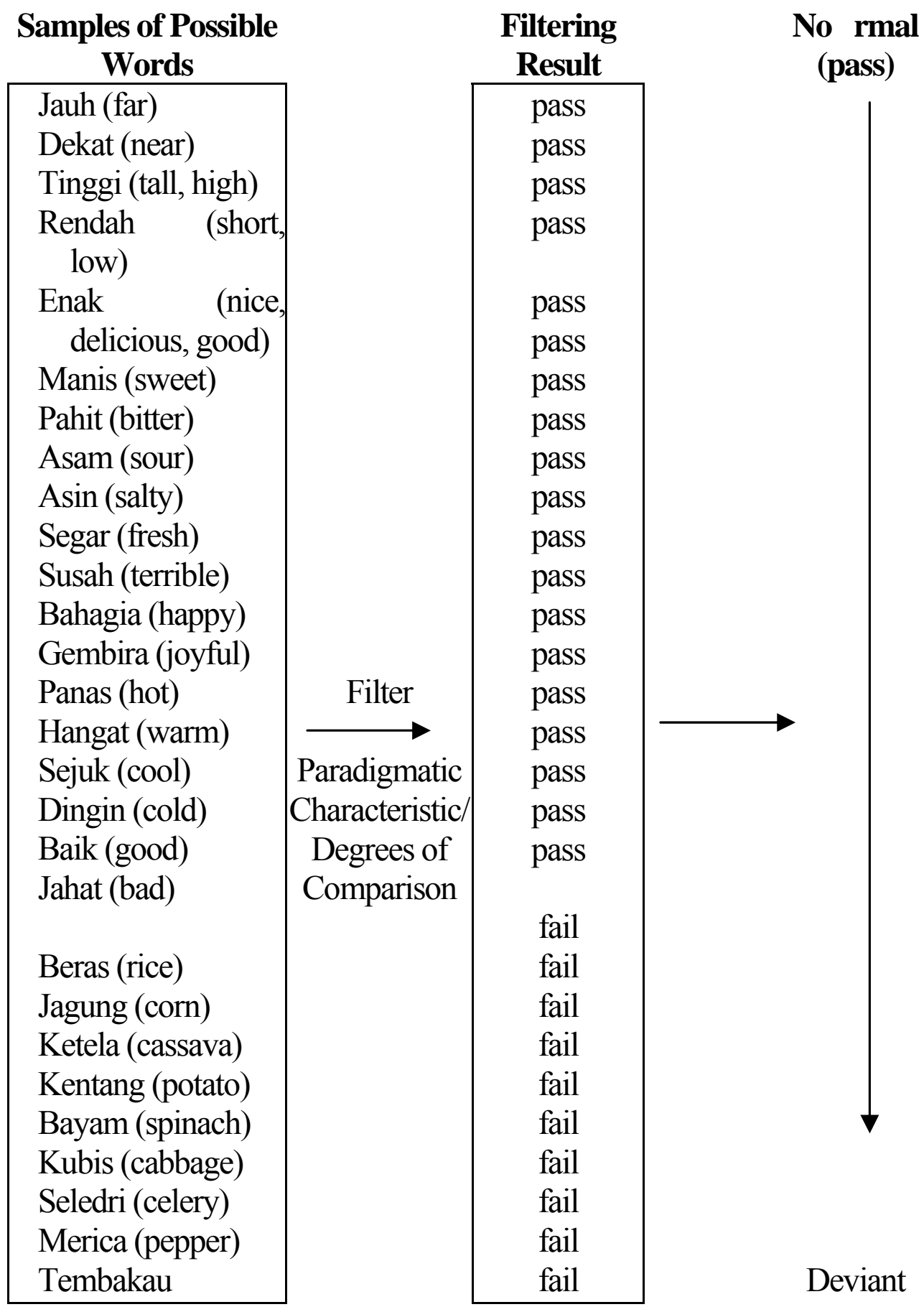

Figure 1. Verbal Flow of the Mechanism of Sign Operations (Fiske, 1982) 
This being the case, this dimension of violation or deviation generates further effects on the readers. All this suggests that creativity or originality frequently means breaking the norms or conventions, and semiotic analysis can help us understand what norms are being deviated from, to what extent and possibly, to what effect. It also suggests that the use of banget in such instances posits a new touch to the hitherto use of banget. We should note, however, that concern about the effect upon the readers of the workings of any aberration of the use of linguistic resources is not the focus of Saussure's theorization of human language. Neither was Saussure concerned with why people, such as advertisers, should violate the syntagmatic-paradigmatic system. Rather, his concern was more on the operational mechanisms of the signs (encompassing signifiers and signifieds). Therefore, as to why Indonesian advertisers and likely (potentially) young Indonesians are now inclined to employ nouns (such as kopi (coffee), jahe (ginger), susu (milk)) and proper name (e.g., Delon, see abovementioned) in the paradigmatic slot of adjectives and/or adverbs is not explainable using Saussure's concept of human language.

Pertinent to the above issue, I would present two hypothetical points. First, such a use of noun in the slot of adjective and/or adverb plus the qualifier banget is probably influenced by the English construction of "the very plus noun" (e.g., the very nature, at the very moment, and so forth). This hypothesis is based on the fact that Indonesians have recently undergone (as any other developing countries) a great exposure to English. This is in particular evidenced by the issuing of the bill on the possibility of teaching English to primary school students through out Indonesia. This is also in line with the development of English materials for the teaching of some content subjects at some Junior High Schools in Indonesia.

Secondly, it might be viewed as a reaction to the falsification that has been spreading across the archipelago. Probably, due to the severe corrupt condition as can be perused in Fahman's (2004) intriguing collection of articles titled Kiai dan Korupsi: Andil Rakyat, Kiai, dan Pejabat dalam Korupsi (Clerics and Corruption: Roles of Citizen, Clerics, and Bureaucrats in Corruption), Indonesians (subconsciously though) have developed a kind of disbelief in people's way in characterizing things by means of adjectives or the attributes of the things. Forgery has made them hard to believe in an ordinary way. Therefore, they try to convince people, when they need, not by using the ordinary adjectives, rather, by mentioning the very things themselves (the nouns, pronouns) and doubling up with the use 
of the qualifier banget (very, pretty, just). We might assume that the use of the words susu banget, kopi banget, jahe banget, Delon banget to refer to their characteristics or attributes leaves no room for counterfeit, for they exactly refer to the things themselves. By means of conclusion, this means that counterfeiting in Indonesia has been pretty severe in that it evokes people to react even with (only) the use of certain words.

The spread of distrust among people is also apparent in the political amphitheater. Political party is now viewed inadequate to carry people's political aspirations. Some elements in the society, particularly university students, have recently rallied to force members of legislative, be they at the central, regional, or local level, to sign for social contract, assuring that the members are committed to common people's vis-à-vis elites' interests and needs. This further gives rise to the need to find ways to convince people when they need one; ordinary emphatic expression by referring to adjectives (characteristics, attributes of nouns or pronouns) is no longer adequately effective. It follows that they have recently started using the more powerful strategy of mentioning the "very things" themselves rather than the attributes or characteristics in order to gain convincing points and adding it with the emphatic expression (e.g., banget, bangeeet, bangeeets). This, subsequently, contravenes the conventional formula of "adjective plus qualifier (emphatic adverb)." The novel formula is "noun or pronoun plus qualifier (emphatic adverb)".

\section{RAMIFICATION AND SELF-CONVICTION}

On the part of language planners, for instance, Pusat Bahasa, Departemen Pendidikan Nasional (Language Center, Department of National Education) (see Alwi, 2002), the issue and the suggested hypothetical interpretation stands on two opposing boards. The linguistic phenomenon at issue can be deemed to constitute a potential leverage for development. Yet, the syntagmatic issue poses a challenge to the existing concept of grammatical correctness in Bahasa Indonesia. Supposing that the grammatical phenomenon above is considered an aberration, the speakers of the expression will tend to be considered unintelligent. However, the fact that the public seems to be willing to accept the grammar demonstrates that the speakers cannot be readily deemed unintelligent. On the contrary, the criticality shown by the public of the corruptive practices in the society suggests intelligence on the part of the speakers. 
As regards the possible influence of English structure (e.g., the very + noun), Alwi's (p. 150) statement - that interference correlates with the degree of one's acquisition of the languages - seems to have some degree of validity. Alwi went on to say that "Pada dasarnya bahasa yang lebih kita kuasai akan mengintervensi bahasa yang kurang kita kuasai" (the language which one acquires better will interfere that which is less acquired). If we accept this latter idea, we are propagating that English is acquired better than Bahasa Indonesia by the public, specifically, those uttering and internalizing the expression of Delon banget, kopi banget, etcetera. This, I am sure, is not the point favored by Alwi, for he disagrees with the notion that English as a foreign language is more prestigious. He states pembinaan yang dilakukan terhadap bahasa asing di Indonesia hendaknya diupayakan agar bahasa asing itu tidak mengorbankan sikap positif masyarakat Indonesia terhadap bahasa Indonesia dan bahasa daerah (attempts to stimulate the acquisition of foreign languages in Indonesia should not be done at the expense of destroying the positive attitudes of the public to Bahasa Indonesia and the local languages) (p. 146).

Another question that warrants attempts to provide interpretive answer is why the public seems to easily accept the grammatical aberration shown in the sample linguistic issues discussed above. My conviction about this issue is that the public has been fed up, consciously or unconsciously, with the corruption in the country. When an expressive vehicle, which gives no room for counterfeit, was coined, they were so ready that they vivaciously started to use it and this is what has been going on about the nonconventional expressions we have discussed.

\section{CONCLUSION}

By way of summarizing, the foregoing discussion has demonstrated that Saussurean theory is powerful for analysis of some Indonesian nonconventional expressions. The operation of the notions of paradigm, syntagm, and convention is central to the analysis the non-conventional expressions. However, it is also interesting to note that why Indonesians (particularly artists and young people) now frequently use nouns to be put in the paradigmatic slot of adjectives (e.g., susu banget, rempah sekali, semakin Indonesia) is unexplainable using Saussure's linguistics. Probably, this is because such a phenomenon has to do with language use or parole 
which, in Saussure's concept, is not to be taken as the proper object of linguistic study. Accordingly, Saussure did not have a pretension to seek for framework to explain this issue.

As the discussion has also shown, the bottom up issue of the grammatical violation is a challenge to language planners - whether they should accommodate or discard it. Accommodating means enrichment of the grammar of Bahasa Indonesia and discarding suggests protection of the well established grammar of Bahasa Indonesia. If we take the first move, we recognize the intelligence (creativity and criticality) of the Indonesians yet, simultaneously, submit to the English interference (if the grammatical violation is believed to be the result of interference of English grammar). If we take the second choice, we waste our own energy which is actually needed for the development of our language.

We need to note in this regard that the non-conventional expressions tend to be conventional along the time. We also need to bear in mind that linguistic innovations (thus language change) tend to initially occur in casual speech (Romaine, 1994). This seems to be what happens with the instances we just discussed. Believing the validity and generalizability of Romaine's observation, the non-conventional expressions at issue in Bahasa Indonesia will ("somewhen" in the future) enter the realm of standard Bahasa Indonesia. When this happens, the non-conventional becomes conventional. However, as to whether the change will constitute a prestige one (Romaine, 1994) is beyond the present discussion.

To come to the point, it is at our disposal whether we take accommodative view and action dealing with the issue we have been hitherto talking about. But what is clear from the above discussion is that Saussure has provided us with linguistic conceptions which are operational for the analysis of the recent Indonesian non-conventional expressions, thus innovations (to borrow Romaine's word). Yet, as to why there is now a burgeoning use of nouns to replace adjectives (paradigmatic and syntagmatic manipulation) is beyond pure Saussure's concepts of human language. Probably, Romaine (1994) is right in suggesting that many issues about language are actually not linguistic but social. This social aspect is to a large extent related to language use or parole which is denied by Saussure as the appropriate object of linguistic study. Accordingly, Saussure does not have due conception about the motives of the emergence of nonconventional expressions as linguistic innovations - the very ingredients of language change (Romaine, 1994). 
We also need to note that those likely using the expressions discussed above tend to be young people. In this regard, we have the memory that since as early as 81 years ago, the Indonesian youth have played their vital role in this country. The Indonesian Youth Pledge (Sumpah Pemuda) in 1928 has utterly demonstrated their primacy over the destiny of the country. The pledge has instigated the formation of élan to combat overriding imperialism across the archipelago, as partly depicted in K'tut Tantri's (2006) Revolt in Paradise, culminating in the country's independence in 1945. And the days following have witnessed yet other pieces of evidence of the exercise of the youth's predominance. This preponderance takes the form of, inter alia, linguistic non-conventional expressions as innovations of some sort.

\section{REFERENCES}

Alwi, H. (2002). Bahasa, daya nalar, dan kecermatan (Language, intelligence, and meticulousness). In A. Syahid, \& A. Al-Jauhari (Eds.), Bahasa, pendidikan, dan agama (Language, education, and religion) (pp. 143-158). Ciputat, Jakarta: Logos Wacana Ilmu.

Aveling, H. (2004). Indonesian literature after reformasi: The tongues of women. Paper presented at the Conference on Indonesian Elections 2004: The End of Reformasi, Nakhon Si Thammarat, Southern Thailand.

Basthomi, Y. (2007). An initial intimation of a yet banal discourse: Truck graffiti. $k @ t a, 9(1), 34-48$.

Basthomi, Y. (2009). Truck graffiti: The rhetoric of emulation. In E. Weigand (Ed.), Dialogue Analysis XI. Retrieved January 9, 2009, from www.unimuenster.de/Ling/iada/download/iada.online.series_volume02.pdf.

Burkette, A. P. (2001). An examination of language variation in a small blue ridge community. Unpublished doctoral dissertation, University of Georgia, Ann Arbor.

Davies, W. D. (2005). Madurese control. k@ta, 7(1), 1-12.

Doyle, B. (1989). English and Englishness. London: Routledge.

Fahman, M. (2004). Kiai dan korupsi: Andil rakyat, kiai, dan pejabat dalam korupsi (Clerics and corruption: Roles of citizen, clerics, and bureaucrats in corruption). Surabaya: Jawa Pos Press. 
Fiske, J. (1982). Introduction to communication studies. London and New York: Methuen.

Flowerdew, J. (2001). Attitudes of journal editors to nonnative speaker contributions. TESOL Quarterly, 35(1), 121-150.

Goss, E. L. (2002). Negotiated language change in early modern Holland: Immigration and linguistic variation in the Hague (1600-1670). Unpublished doctoral dissertation, University of Wisconsin-Madison, Ann Arbor.

Nawata, H. (2000). Locality of language change: A study of diachronic feature shift in English. Unpublished doctoral dissertation, Nagoya University, Ann Arbor.

Norton, B. (1997). Language, identity, and the ownership of English. TESOL Quarterly, 31(3), 409-429.

Palupi, M. G. R. (2006). Communicative acts performance of an Indonesian child. k@ta, 8(2), 137-154.

Rice, P., \& Waugh, P. (Eds.). (1992). Modern literary theory: A reader $\left(2^{\text {nd }}\right.$ ed.). London: Edward Arnold.

Romaine, S. (1994). Language in society: An introduction to sociolinguistics. Oxford: Oxford University Press.

Saussure, F. M. (1959). Course in general linguistics. New York: McGraw-Hill Book Company.

Susanto, J. (2007). Codeswitching in islamic religious discourse: The role of Insha'Allah. Religion and Science, 3(1), 217-248.

Tantri, K. (2006). Revolt in paradise. Jakarta: PT Gramedia Pustaka Utama. 